Indonesian Journal of Biotechnology, June, 2015

Vol. 20, No. 1, pp.42-53

\title{
Induction of Somatic Embryogenesis through Overexpression of ATRKD4 Genes in Phalaenopsis "Sogo Vivien"
}

\author{
Exsyupransia Mursyanti ${ }^{1,2}$, Aziz-Purwantoro ${ }^{1,3}$, Sukarti Moeljopawiro ${ }^{1,4}$, and \\ Endang Semiarti ${ }^{1,4 *}$
}

\begin{abstract}
${ }^{1}$ Biotechnology Study Program, Graduate School, Universitas Gadjah Mada, Yogyakarta, Indonesia ${ }^{2}$ Faculty of Technobiology, Universitas Atma Jaya Yogyakarta, Yogyakarta, Indonesia

${ }^{3}$ Faculty of Agriculture, Universitas Gadjah Mada, Yogyakarta, Indonesia

${ }^{4}$ Faculty of Biology, Universitas Gadjah Mada, Yogyakarta, Indonesia
\end{abstract}

\begin{abstract}
Phalaenopsis "Sogo Vivien "is a mini orchid hybrid with beautiful flowers and numerous inflorescences. Mass propagation of this orchid is needed to meet the market demand. Objective of this research was to induce somatic embryogenesis of P."Sogo Vivien" through insertion of AtRKD4 gene into orchid. T-DNA containing 35S::GAL4::AtRKD4::GR was inserted into 16-22 days after sowing orchid protocorms mediated by Agrobacterium tumefaciens EHA 105. Activation of the AtRKD4 gene was induced by glucocorticoid induction system, using $15 \mu \mathrm{M}$ Dexamethasone (Dex). The results showed that 34 out of 2,648 orchid embryos developed into protocorms on hygromycin selection medium, whereas only 4 out of 2,897 non-transformant protocorms developed from embryos. A $500 \mathrm{bp}$ of HPT genes was amplified from transformant candidates using specific primers for HPT (HygF1 and HygR1) and $380 \mathrm{bp}$ was amplified using specific primers for AtRKD4 (AtRKD4 F1 and AtRKD4 R1), indicated that transgenes have been integrated into orchid genomes. Finally, 17 plantlets were positively carrying AtRKD4 and HPT genes, the efficiency of transformation was $0.63 \%$. Somatic embryos were also emerged from leaf explants of transformant on hormone-free NP medium and became normal plantlets. It is probably due to the high activity of AtRKD4 genes in orchids.
\end{abstract}

Keywords: AtRKD4, glucocorticoid, Phalaenopsis "Sogo Vivien", orchid hybrid, somatic embryo

\section{Introduction}

Phalaenopsis "Sogo Vivien" is an orchid hybrid with beautiful striped purple flowers and dark purple labellum and variegated leaves, define as green leaves having golden yellow ribbon on their edges (McKinley, 2005). With its mini size and many flowers, the orchid is included in the desired criteria for pot plants (Tang and Chen, 2007).

Conventional propagation by using the buds could produce shoots, but it is inefficient because it needs a long time and produces an only small number of plants due

\section{*Corresponding author:}

Endang Semiarti

${ }^{3}$ Faculty of Biology, Universitas Gadjah Mada, Yogyakarta, Tel/Fax:62-274580839

E-mail: endsemi@ugm.ac.id to each bud produces only one plant (Kosir et al., 2004). Propagation using seeds is highly depending on the fruits that resulted from pollination. Therefore, it needs an effective propagation method to produce uniform seedlings in large numbers and in relatively short time.

A breakthrough, which could increase the efficiency of orchid micropropagation is by combining the micropropagation method and the genetic engineering. Agrobacterium tumefaciens-mediated genetic transformation method was used to produce a variety of orchid plants (Semiarti et al., 2007; Semiarti et al., 2010; Sreeramanan and Zuraida, 2010).

In plants, some genes involve in somatic embryogenesis. Some of the genes that responsible for the initiation and development of embryogenesis have been 
identified (Radoeva and Weijers, 2014), some of which induce ectopic embryogenesis on the model plant of Arabidopsis thaliana, the LEAFY COTILEDON (LEC) genes (Braybrook and Harada, 2008 ), BABY BOOM (BBM) gene (Boutilier, 2002), WUSCHEL (WUS) homeobox gene (Zuo et al., 2002) and RWPRKDOMAIN CONTAINING-4 (RKD4) (Waki et al., 2011).

RKD4 gene encodes a protein with RWP-RK motif in Arabidopsis required for embryonic pattern formation (Chardin et al., 2014). This gene encodes a transcription factor protein that expressed very early in zygotic embryogenesis (Waki et al., 2011). Waki et al. (2011) inserted indRKD4ox genes into Arabidopsis and proved that overexpression of these genes after induction using synthetic steroid hormones such as Dexamethasone (Dex) on the roots of $A$. thaliana transformant, produced somatic embryos.

Utilization of glucocorticoid regulation system is a general tool for regulating gene expression in plant cells and whole plants. Expression of the glucocorticoid receptor protein from a stage- or tissuespecific promoter in plants could conceivably provide a way to target glucocorticoidinducible gene expression to specific times in development or to specific plant tissues. Experiment with transgenic plants expressing the glucocorticoid receptor was conducted by Schena et al. (1991) that determined the extent to which glucocorticoid induction can be achieved in A.thaliana. The mammalian steroid receptors can be used function as hormone-dependent inducers of gene expression in heterologous systems, and the feasibility of using mammalian steroid hormones as selective inducers of plant gene expression was investigated. Schena et al. (1991) found that in glucocorticoid induction system, the treatment with glucocorticoid hormone can activate the glucocorticoid receptor expression in plant cells. This system can be used to activate a test gene linked to glucocorticoid response element. These findings indicate that glucocorticoid induction of steroid responsive promoters provide a general method for regulating gene expression in plant cells, and imply that such a system might ultimately function in whole plants such as A. thaliana and others. Overexpression of the transgene in these systems could only be induced in transgenic plants when there is glucocorticoid response element in the plant genome and the existence of glucocorticoid hormone in the medium (Kang et al., 1999). Dexamethasone as glucocorticoid hormone was successfully used to induce the expression of Myc-XA21 gene in transgenic rice plants (Park et al., 2012) and to activate Luc genes in A. thaliana transgenic (Aoyama and Chua, 1997). However, the technique of embryo somatic induction using glucocorticoid system in orchids, mainly $P$ "Sogo Vivien", has not been reported.

In this paper we report the use of glucocorticoid selective inducible system to overexpress AtRKD4 transgene in orchid for inducing somatic embryogenesis of $P$. "Sogo Vivien" orchid hybrid.

\section{Materials and Methods \\ Plant material and culture conditions}

Plant material used in this study was $P$. "Sogo Vivien" orchid hybrid obtained from CV. Amabilis nursery, Kiaracondong, Bandung. Four-year-old flowering plants were planted in the pots with sphagnum moss medium, maintained in a greenhouse under natural lighting at temperatures between $(25 \text { and } 30)^{\circ} \mathrm{C}$. Mature pods from self-pollinated flowers of variegated $P$. "Sogo Vivien" plants were used as plant materials for all of the experiments.

\section{Seed plantation for protocorms preparation}

A three-month-old orchid pod from self pollinated variegated $P$. "Sogo Vivien" was used as a seed source. The pod was subsequently sterilized by dipping it in alcohol and then flame it on a Bunsen lamp. Next, the seeds were sowed on NP medium 
(Islam et al., 1998). Intensive observation was conducted every day to observe the development stage of the seeds that grew into protocorms, which was carefully examined using a stereo microscope (Eschenbach Binoculars DM150DB, Germany), and were photographed using digital camera (Canon A2300 HD, Japan), and Optilab (Miconos, Indonesia) with LED light system.

\section{Plasmid vector and bacterial strain}

The plasmid used was pTA7002 with the T-DNA construction of 35S::GAL4::AtRKD4::GR (obtained from Dr. Jose Gutierrez-Marcos, University of Warwick, UK; Fig.1), which was contained in Agrobacterium tumefaciens strain EHA105. Isolation of plasmid was conducted using the alkali lysis method (Green and Sambrook, 2012). The T-DNA consists of multiple strong promoters 35S, GVG, GAL 4 and VP16 with Glucocorticoid response element (GRE) for selective inducible system with glucocorticoid hormone (Dexamethasone). For antibiotic selective system, Hygromycin phosphotransferase (HPT) was driven by Nophaline Synthase (NOS) promoter and the target gene AtRKD4 from $A$. thaliana.

\section{Transformation and regeneration of transformants}

Overnight cultures of Agrobacterium in LB medium were diluted $1: 4(\mathrm{v} / \mathrm{v})$ using NP liquid medium supplemented with $2 \%$ $(\mathrm{w} / \mathrm{v})$ sucrose, a phenolic natural product acetosyringone $50 \mathrm{mg} . \mathrm{L}^{-1}$ (Bio Basic, Canada). Three-weeks-old protocorms were immersed in the diluted culture of Agrobacterium for an hour, then transferred its onto sterile nylon cloth to dry in laminar air flows and then transferred onto modified NP solid medium containing 2 mg.L - $^{-1}$ 2,4-D (Sigma), 100 g.L - $^{-1}$ tomato extract, and $25 \mathrm{mg} . \mathrm{L}^{-1}$ acetosyringone, for cocultivation. At day-3, protocorms were washed 3 times using sterile distilled water, then soaked it in a half-strength of NP liquid medium without antibiotics, protocorms then shaken using a shaker with the speed of 100 rpm for 2 nights, the medium was renewal every 24 hours. Next, protocorms were rinsed 3 times using sterile distilled water, drained again for $30 \mathrm{~min}$. Once dried, protocorms were transferred onto solid NP medium containing $25 \mathrm{mg}$. $\mathrm{L}^{-1}$ meropenem (Sanbe) to inhibit the growth of Agrobacterium, and were cultured for a week. After that, protocorms were moved onto NP medium (selection medium) containing $25 \mathrm{mg}$. $\mathrm{L}^{-1}$ meropenem and 10 mg.L $\mathrm{L}^{-1}$ hygromicin (Wako, Japan), for selection of the transformants. The developing protocorms were later transferred onto a new medium for every 2 weeks for further selection of the transformants. Developing shoots as the candidate of transformants were screened by PCR using AtRKD4 and HPT-specific primers to confirm that they were the succesful transformants. Efficiency of transformation was measured from the number of positive transformants for both HPT and AtRKD4 transgene in the genome per total protocorms examined, multiply by $100 \%$.

\section{Polymerase chain reaction analysis of transformants}

Genomic DNA from the putative 35S::GAL::AtRKD4::GR transformants was analyzed by direct PCR using KAPA3G Plant PCR Kit (KapaBiosystem), using specific primers for the AtRKD4 gene: AtRKD4F, 5- GTTCATTTCATTTGGAGAGGACG-3 ; AtRKD4R, 5- CTTCCATATCTAGGAGAG AAT CAAG-3 and specific primers for the

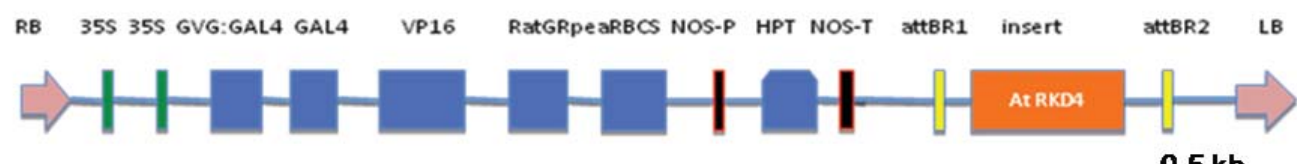

$0.5 \mathrm{~kb}$

Figure1. The structure of T-DNA carrying 35S::GAL4::AtRKD4::GR in plasmid pTA7002/EHA 105 
HPT gene: $H y g F$, 5-TCGGACGATTGCGTCG CATC-3; HygR, 5- AGGCTATGGATGC GATCGCTG-3. PCR for both genes was performed with 30 cycles of $95{ }^{\circ} \mathrm{C}$ for 30 $\mathrm{s}, 58^{\circ} \mathrm{C}$ for $30 \mathrm{~s}$, and $72^{\circ} \mathrm{C}$ for $30 \mathrm{~s}$ using a Thermal Cycler (Biorad T100 $\left.{ }^{\mathrm{TM}}\right)$. Amplified DNA fragments were separated on a 1,4\% agarose gel (Sigma), stained with SYBR Safe DNA Gel Stain (Invitrogen), and visualized under Ultraviolet Viewer (ExtraGene).

\section{Induction of embryo somatic and Analysis of AtRKD4 gene expression}

The leaves originated from plantlets, which grown on selection medium were subsequently taken and cut into pieces, and then planted on NP medium containing 15 $\mu \mathrm{M}$ Dexamethasone (Dex, Merck) for a week in order to induce somatic embryo formation. After that, the leaf pieces were transferred onto hormone-free NP medium. Observations were performed on the development of leaf explants to examine and count the number of somatic embryos using a stereo microscope, Optilab and photographed using a digital camera.

\section{Results and Discussion}

The growth of protocorms as the target of transformation

The seeds were obtained from a healthy mother plant of $P$. "Sogo Vivien", that produced good quality of seeds in three months old mature fruit/pod (Fig. 2).
Development of zygotic embryos in the seeds of $P$. "Sogo Vivien" into protocorms on NP medium was observed intensively for one month (Fig. 3). At day 0, the embryo was white yellowish in color surrounded by testa (Fig. 3a). It gradually grew into swollen embryo at day 5 with the volume become twice bigger than before (Fig. 3b). Later, the color of embryo were gradually changed into yellow-green (Fig. 3d-e) and then turned to green (Fig 3f). At 29 days after sowing (DAS), absorbing hairs were gradually emerged from the basal part of the embryos and the growth of embryo significantly increased up to 6 times (Fig. 3f). In this study, seeds were planted on solid NP medium containing $150 \mathrm{~mL} . \mathrm{L}^{-1}$ coconut milk and covered by nylon cloth to facilitate convenient technique on protocorm harvesting prior to genetic transformation. Based on morphological change (size, color, shape, and the emergence of absorbing hairs) of embryo into protocorm, it can be classified into five phases as follow: Phase 1 (5 DAS)-seeds had swollen embryo due to water uptake from the medium, white yellowish in color, and most of testa (seed coat) had broken (Fig.3b); Phase 2 (11 DAS)- enlarged embryos, they were white yellowish in color and globular in shape (Fig. 3c); Phase 3 (16 DAS)- the embryo enlarged and changed the color from white to yellow, the polarity of the embryo appeared bipolar, where the anterior part was yellow-green in color, and the posterior part was yellowish (Fig. 3d). Phase 4 (21 DAS)-the embryo enlarged

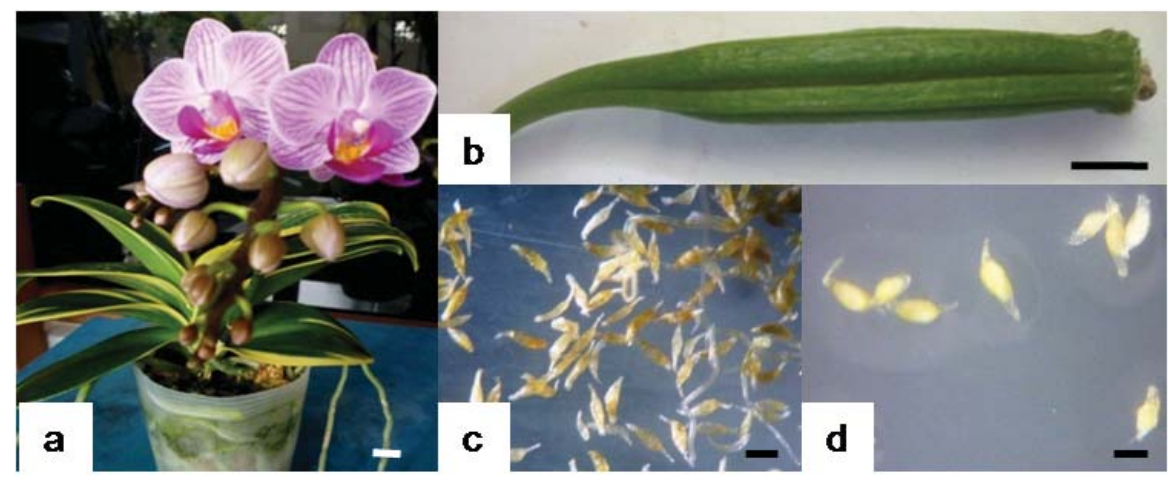

Figure 2. Phenotype of Phalaenopsis "Sogo Vivien" orchid hybrid. (a) Mother plant; (b) self-pollinated fruit; (c) seeds before planting and (d) seeds at 2- days after sowing (DAS) on NP medium. Bars: $5 \mathrm{~mm}$. 

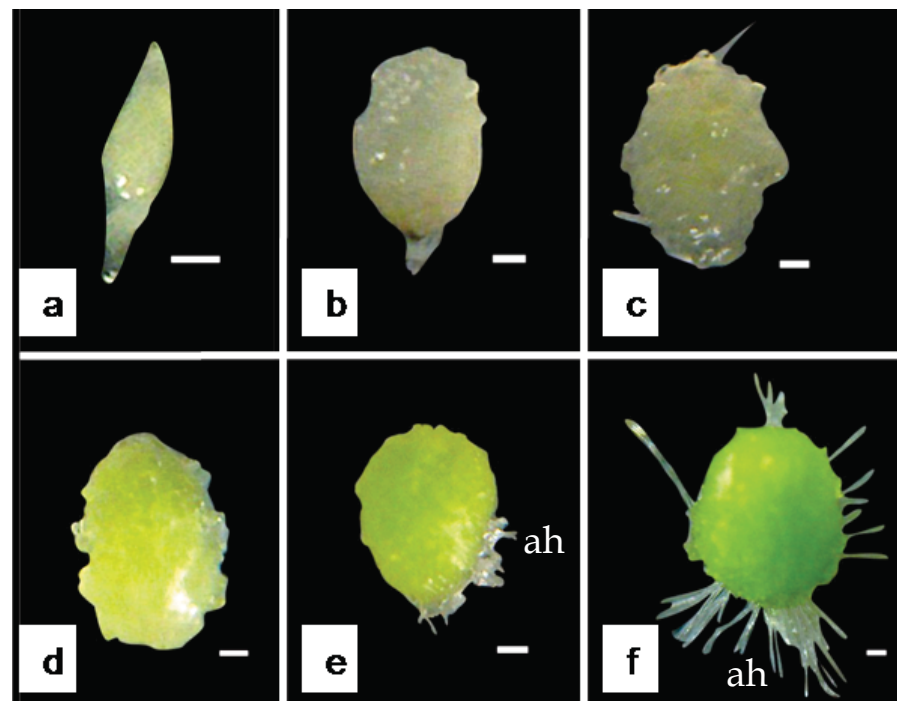

Figure 3. Development of Phalaenopsis "Sogo Vivien" orchid embryos on NP medium. (a). 0 DAS; (b). Swollen embryo with broken testa at 5 DAS; (c). yellowish embryo at 11 DAS; (d). Yellow-green embryo at 16 DAS; (e). Greenish embryo with absorbing hair at 21 DAS; (f). Bright green embryo with many numbers of absorbing hairs (ah) at 29 DAS. Bars $0.1 \mathrm{~mm}$.

and changed the yellow color to green, and started to exhibit absorbing hairs (Fig. 3e). Phase 5 (29 DAS)- the embryo enlarged with green color, the anterior part showed leaf primordia, and had much number and more dense of absorbing hairs (Fig. 3f). Based on the morphological changes during embryo development of $P$. "Sogo Vivien", therefore protocorms in phase 4 ( 21 DAS) (Fig.3a) were selected in this study as the target for genetic transformation using Agrobacterium.

This phenomenon was very similar to that of embryo development in the wild orchid Phalaenopsis amabilis as reported by Semiarti et al. (2007), inwhich 21 DAS protocorms were used as the target for Agrobacterium-mediated transformation. Bunnag and Pilahome (2012) have also used protocorms as the transformation target. Although many researchers used protocormlike bodies (plb) as the target for the genetic transformation in orchids (Chan et al., 2005; Shrestha et al., 2007; Subramaniam et al., 2009; Zhang et al., 2010).

The use of protocorms as transformation target has several advantages, i.e. it can easily and quickly produced in large quantities as it comes from the growth of seeds, it has a high level of regeneration, and it allows transfer of genes into protocorm (Mishiba et al., 2005).

\section{Regeneration and selection of hygromycin- resistant protocorms}

Genetic transformation using protocorms was conducted in several steps, namely the pre-culture of protocorms, co-cultivation of protocorm with bacteria carrying the recombinant DNA, elimination of bacteria, selection of transformants candidate, and regeneration of transformant candidates. The medium used for preculture contained 2,4-D, tomato extract and acetosyringone, which aimed to keep the meristematic level of protocorm, protected from oxidative damage, and to improve the response level of protocorm when gene transfer was performed (Mishiba et al., 2005 ; Semiarti et al., 2010; Dwiyani et al., 2010). In this research, co-cultivation was carried out in 3 days to optimize the integration of T-DNA into the genome of protocorms. For the elimination of bacteria, 


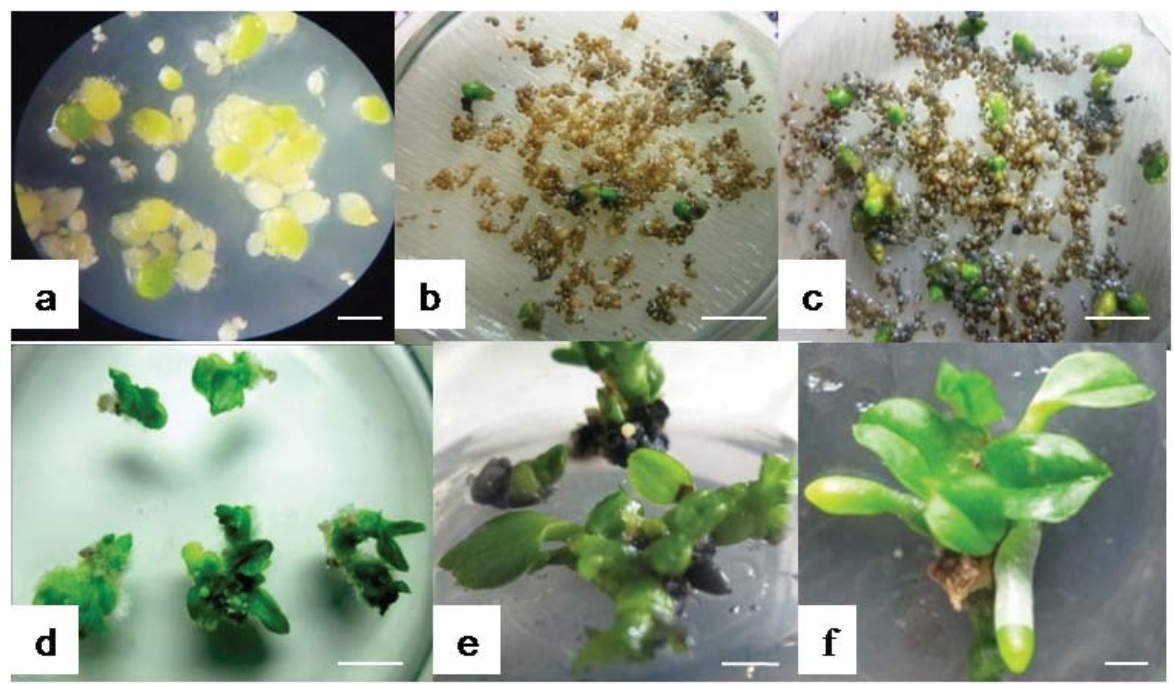

Figure 4. Regeneration of Phalaenopsis "Sogo Vivien" transgenic plants from protocorms. (a) 3 weeks after sowing (WAS)-protocorms used as transformation target; (b-c) 9-WAS of Non-transformant protocorms grown on hygromicin selection medium (b); and Transformant line \#1 (T\#1) protocorms which are able to form buds on selection medium (c); (d) 16-WAS T\#1 protocorms, which are able to regenerate into plantlets; (e-f) Regenerated T\#1 plants at 18-WAS (e) and at 22-WAS (f). Bars $1 \mathrm{~mm}$ in a, $5 \mathrm{~mm}$ for $b-f$.

antibiotics meropenem was used as it could effectively disturbed the growth of Agrobacterium (Mishiba et al., 2005). The selection of transformant candidates was done in 6 weeks with intensive subcultured for every 2 weeks on selection medium containing hygromycin $10 \mathrm{mg} . \mathrm{L}^{-1}$. The use of the antibiotics was in accordance with the existance of $H P T$ gene in T-DNA that caused it resistance to hygromycin (Fig.4).

Total number of protocorm that able to grow on hygromycin selection medium was 46 protocorms, generated from 3-times-experiments with 2,648 transformed protocorms examined (Table 1, Fig.4). A total 34 protocorms formed buds on selection medium (Fig.4c) and of these only 20 protocorms were able to regenerate into plantlets (Fig.4d). Almost all of nontransformant protocorms were unable to grow on selection medium containing hygromicin, only 6 out of 2,897 protocorms could grow, the others embryos were turned the color into dark brown, due to browning process and necrosis (Fig.4b). Overall, the morphology of the transformant plant candidates were relatively similar to their wildtype plant (Fig. 4e, 4f). The average of transformation frequency obtained from 3-times-experiment was relatively low, about $0.63 \%$, as shown by that very view number of protocorms undergone genetic transformation.

Opabode (2006) stated that the main factors causinglow efficiency of transformation is the hypersensitive plant defense reaction against Agrobacterium infection inducing excessive production of reactive oxygen species (ROS). This compound is highly reactive towards biomolecules, which cause damage of plant tissue followed by browning and necrosis (Kuta and Tripathi, 2005). Several studies of genetic transformation using Agrobacterium with transformation targets in the form of protocorm-like bodies (plb) and orchid protocorm obtained transformation efficiency of $4.3 \%$ in Cattleya (Zhang et al., 2010); $1.91 \%$ in Phalaenopsis hybrid (Mishiba et al., 2005); $1.7 \%$ in Phalaenopsis amabilis (Semiarti et al., 2007); and 1.3 to $2.7 \%$ in 
Table 1. Efficiency of transformation of Phalaenopsis "Sogo Vivien"

\begin{tabular}{|c|c|c|c|c|c|c|c|c|}
\hline & \multirow[t]{2}{*}{ Experiment } & \multirow{2}{*}{$\begin{array}{c}\text { No. of } \\
\text { protocorms } \\
\text { examined }\end{array}$} & \multirow{2}{*}{$\begin{array}{l}\text { Positive } \\
\text { selective } \\
\text { medium }\end{array}$} & \multirow{2}{*}{$\begin{array}{l}\text { No.of } \\
\text { protocorm } \\
\text { producing } \\
\text { shoot }\end{array}$} & \multirow{2}{*}{$\begin{array}{l}\text { No. of } \\
\text { regenerated } \\
\text { plants }\end{array}$} & \multicolumn{2}{|c|}{ PCR Detection } & \multirow{2}{*}{$\begin{array}{c}\text { Efficiency } \\
\text { of transfor } \\
\text { mation }(\%)^{*}\end{array}$} \\
\hline & & & & & & HPT+ & AtRKD4+ & \\
\hline \multirow{4}{*}{$\begin{array}{l}\text { Non- } \\
\text { transformant } \\
\text { (NT) }\end{array}$} & 1 & 762 & 6 & 3 & 2 & $0 / 2$ & $0 / 2$ & 0 \\
\hline & 2 & 869 & 6 & 3 & 2 & $0 / 2$ & $0 / 2$ & 0 \\
\hline & 3 & 1266 & 8 & 4 & 3 & $0 / 5$ & $0 / 5$ & 0 \\
\hline & Total & 2897 & 20 & 10 & 7 & $0 / 9$ & $0 / 9$ & 0 \\
\hline \multirow{4}{*}{$\begin{array}{l}\text { 35S:: GAL4:: } \\
\text { AtRKD4:: GR }\end{array}$} & 1 & 1044 & 19 & 14 & 9 & $8 / 9$ & $8 / 9$ & 0.77 \\
\hline & 2 & 842 & 15 & 11 & 7 & $5 / 7$ & $5 / 7$ & 0.59 \\
\hline & 3 & 762 & 12 & 9 & 4 & $4 / 4$ & $4 / 4$ & 0.52 \\
\hline & Total & 2648 & 46 & 34 & 20 & $17 / 20$ & $17 / 20$ & $\begin{array}{c}0.63 \\
\text { (Average) }\end{array}$ \\
\hline
\end{tabular}

* The calculation of the efficiency of transformation see materials and methods

Oncidium and Odontoglossum (Raffeiner et al., 2009). To improve the transformation efficiency, there are many studies using a variety of treatments, such as the provision of antioxidants, desiccation of transformation target before and after infection with Agrobacterium, length of co-cultivation time, density of Agrobacterium tumefaciens used in the transformation, temperature of co-cultivation process, and the addition of surfactant at the time of Agrobacterium tumefaciens infection to the explants (Opabode, 2006). The low transformation efficiency in $P$. "Sogo Vivien" might caused by the low capability of protocorms to face the oxidation processes as a response to infection by Agrobacterium.

\section{Molecular analyses of transformants}

Molecular analysis to confirm the existance of AtRKD4 and the HPT genes in the genome of transformant plants was performed on plantlets of transformant candidates that grown on medium containing $10 \mathrm{mg} . \mathrm{L}^{-1}$ hygromycin. Seventeen plantlets out of 20 transformant plant candidates showed positive results for both the existance of AtRKD4 and HPT genes in the genome, indicated by the detection of amplified DNA fragments in the size of $500 \mathrm{bp}$ of HPT genes in electrophoresis gel (Fig. 5 lane 4-6) and
$380 \mathrm{bp}$ of AtRKD4 (Fig.5 lane 11-13) and the summarize data in Table 1 . The bands did not appear on the samples of nontransformant plantlets (Fig.5 lane 3 and lane 10). As a positive control, the PCR reaction and electrophoresis was performed using plasmid pTA7002 that contained T-DNA carrying 35S::GAL::AtRKD4::GR construct, and resulted a $380 \mathrm{bp}$ DNA band for AtRKD4 gene (Fig. 5 lane 2) and 500bp DNA band for HPT gene (Fig. 5 lane 9). These data showed that the T-DNA constructs were successfully integrated into the genome of the $P$. "Sogo Vivien" transformant candidates.

\section{Phenotypes of orchid transformants expressing AtRKD4 genes}

To induce overexpression of AtRKD4 gene in the genome of $P$. "Sogo Vivien" transformant candidates, glucocorticoidinducible system using Dexamethasone (Dex) were generated. This is important to do because the T-DNA construct in pTA7002 plasmid contained glucocorticoid response element (GRE) that can be activated after the treatment of glucocorticoid hormone to the plants. For inducing AtRKD4 gene expression, leaves were taken from 3.5 months old positive transformants plantlet $\# 1$ on selection medium (T\#1). The T\#1 leaves were cut into pieces and planted on 


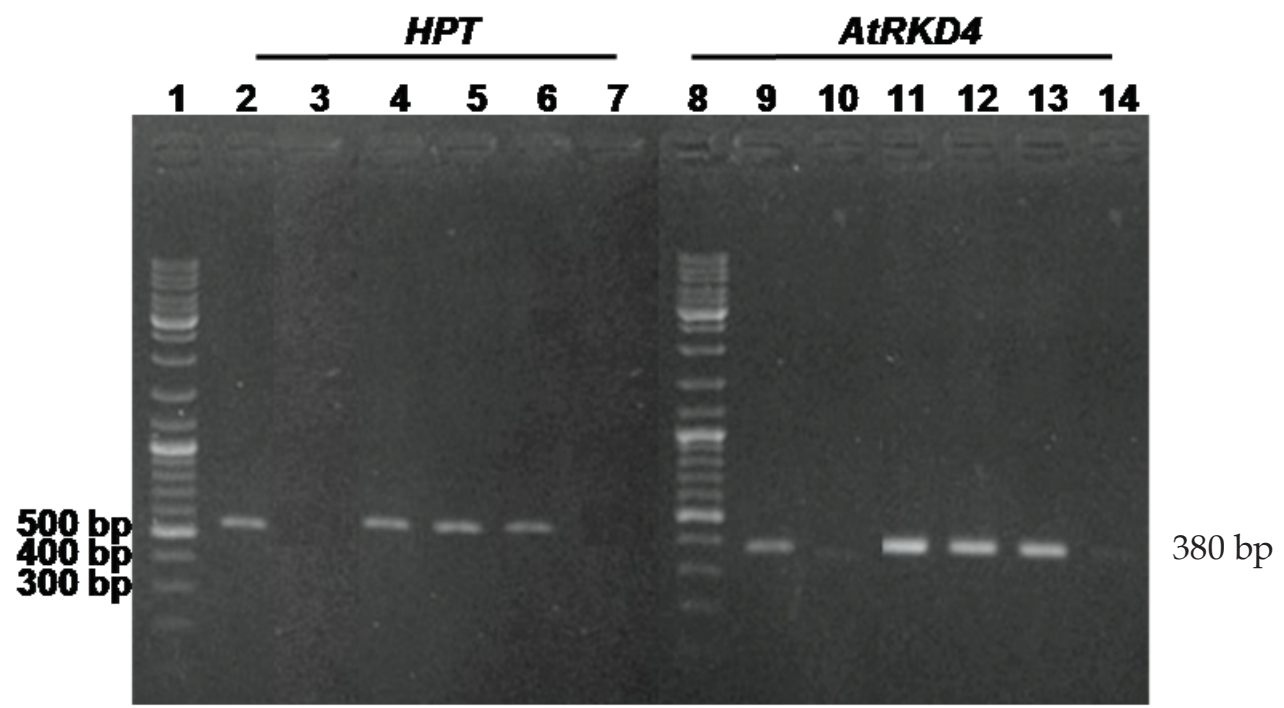

Figure 5. Detection of HPT and AtRKD4 genes integration in the genom of $P$. "Sogo Vivien" transformants. Lane 1 and 8: 1000 bp DNA ladder as size maker; lane 2: amplified 500 bp DNA fragment of HPT gene from pTA7002 plasmid; lane 4-6 transformant candidates $\mathrm{T} \# 1, \mathrm{~T} \# 6, \mathrm{~T} \# 11$, respectively; lane 7: T\#13 transformant candidate that produced no band. Lane 9-14 indicated $380 \mathrm{bp}$ AtRKD4 DNA fragment: Lane 9 from pTA 7001; lane 10: Non transformant plants; lane 11-13 Transformants candidates T\#1, T\#6, and T\#11, respectively; Lane 14: T\#13 transformant candidate that produced no band.

NP solid medium containing $15 \mu \mathrm{M}$ Dex for 1 week. Furthermore, the leaf pieces were subcultured on Dex-free NP medium.

The results showed that somatic embryos were emerged from $\mathrm{T} \# 1$ leaf pieces that grown on hormone-free NP medium (Fig.6). However, there was not observed in all pieces of leaves from NT plants, in which they quickly became browning and finally death. In T\#1 leaf pieces, the somatic embryo formation began with the swelling leaves on day-8, followed by the formation of preglobular somatic embryos on day-18, then it developed to globular embryo at day-33, the shape was very clear after reach day-59. The observation showed that the formation of somatic embryos was occurred on the entire surface of the leaf on the average 72 somatic embryos produced per $0.5 \mathrm{~cm}^{2}$ leaf pieces at day-80. Regenerated plantlets from somatic embryos were obtained at day-140, that showed normal phenotype similar to the phenotype of original non transformant plant (Fig.6). This data showed that overexpression of AtRKD4 gene had been induced by
Dexamethasone and was able to function in orchid to form somatic embryos from leaf pieces of T\#1 transformant plant, that finally produced 413 plantlets (Table 2 ).

Glucocorticoid-inducible expression system is a system that uses regulatory mechanisms of steroid hormone receptors to induce the expression of a gene. This system contains components GVG gene that produces the protein as a transcription factor that regulates glucocorticoids, and components of the gene to be inserted into a plant (Aoyama and Chua, 1997). Transgenic plants which carry plasmids with glucocorticoid-inducible system will express the inserted genes when the glucocorticoid compound was present (Kang et al., 1999). Waki et al. (2011) reported that in Arabidopsis thaliana plants, the steroid compound in 10 $\mu \mathrm{M}$ Dexamethasone can induce AtRKD4 gene expression to the formation of somatic embryos from cotyledons and roots of $A$. thaliana transformants. One hour treatment of Glucocorticoid hormone (in Dexamethasone) in this research could induced cell 


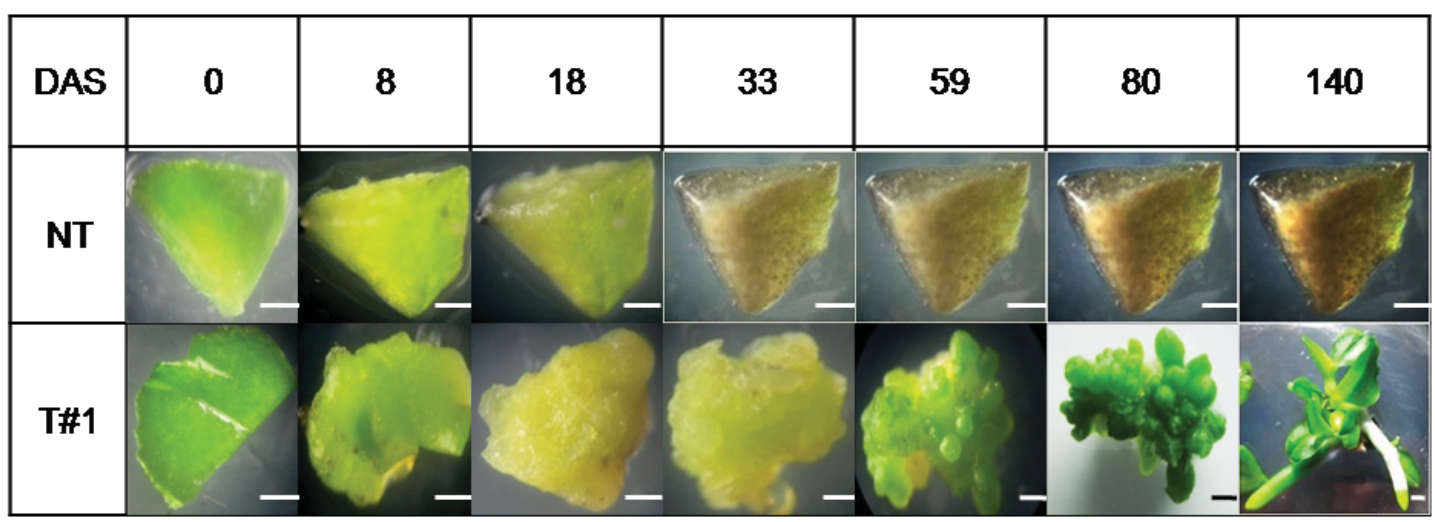

Figure 6. Formation of somatic embryos from leaf explants of $P$. "Sogo Vivien" T\#1 transformant after induction by dexamethasone (Dex). Somatic embryos were induced at 8 DAS by 15uM Dex that showed enlarged size of leaf explants, followed by the formation of embryo at 18 DAS. Pre-globular embryos were observed at 33 DAS, followed by the formation of propagules at 59 DAS, leaf primordia were emerged from the propagule produced shoots at 80 DAS. Finally, each shoot continued their growth into plantlet at 140 DAS. On the other hand, the growth of somatic embryo was not observed from non-transformant (NT) leaf explants. Bars: $1 \mathrm{~mm}$.

Table 2. The growth of somatic embryo from leaf explants of $\mathrm{T} \# 1$ transformants after dexamethasone (Dex) induction

\begin{tabular}{ccccc}
\hline Experiment & $\begin{array}{c}\text { No. of explants } \\
\text { examined }\end{array}$ & $\begin{array}{c}\text { No. of explants } \\
\text { responded }\end{array}$ & $\begin{array}{c}\text { the occurrence of } \\
\text { somatic embryo (days) }\end{array}$ & $\begin{array}{c}\text { No. of somatic } \\
\text { embryo }\end{array}$ \\
\hline 1 & 5 & 3 & 18 & 187 \\
2 & 5 & 2 & 17 & 81 \\
3 & 5 & 3 & 20 & 145 \\
\hline Total & 15 & 8 & & 413 \\
\hline
\end{tabular}

proliferation leaf pieces, that could grow into whole plants after subcultured on Dex-free medium, indicates that undergone each cell proliferation will form a structure resembling embryo and will further develop into plantlet. This is in accordance to the result of Schena et al. (1991) that nanomolar concentrations of glucocorticoids are sufficient to induce gene expression more than 150-fold, without causing detectable alterations in the physiology of the cultured plant cells.

The advantages of glucocorticoidinducible expression system are non-toxic, have no physiological negative effect, allowing the induction of the target genes without pleiotropic effect, induce the target gene rapidly (glucocorticoid can easily permeate plant cell), no visible damage to leaves if glucocorticoid is accumulated, very flexible because it possible to develop another steroid induction system in combination with the GVG system, widely applicable to many genes and in different species of transgenic plants (Aoyama and Chua, 1997). The use of the induction system with glucocorticoid is highly efficient, when compared to the other methods. In transgenic technology of plants, generally induction of foreign gene expression was conducted by providing strong promoter(s) such as the Cauliflower Mosaic Virus-35S promoter (Semiarti et al., 2007), regulatory protein Gal4 from Saccharomyces cerevisiae (Liu and Lehman, 2008), or the herpes simplex virus VP16 as a regulatory switch (Wysocka and Herr, 2003) that positioned upstream of the transcription unit of the foreign gene to be regulated, so as to force the foreign gene can be expressed. But, it could not in this case, 
Mursyanti et al.

because of the constitutive promoters always active continously, therefore we could not set when the gene to be expressed, whereas using gucocorticoid induction system it could be determined when a foreign gene to be expressed. This will give great benefit to researchers who want to know the expression and function of the foreign gene in a specific region and period during transgenic plants development.

\section{Conclusion}

Somatic embryos of Phalaenopsis "Sogo Vivien" can be induced by overexpression of AtRKD4 gene of Arabidopsis thaliana through Agrobacterium-mediated genetic transformation method. Insertion of T-DNA carrying 35S::GAL::AtRKD4::GR construct into 21 day old protocorms through $A$.tumefaciens strain EHA 105 produced 17 transformant plants, the efficiency of transformation was $0.63 \%$. A total 413 plants were regenerated from leaf pieces of Orchid Transformant line \#1 after 1 hour induced by $15 \mu \mathrm{M}$ Dex, then maintained on Dex-free NP medium. All somatic embryos were able to regenerate into normal phenotype of plantlets, which were morphologically similar to the mother plants.

\section{Acknowledgement}

This research was supported by The Ministry of Research, Technology, and Higher Education Indonesia: E.M. is supported by Doctoral Research Grant (Hibah Doktor) 2016 for Atmajaya University, Yogyakarta, Indonesia. E.S and A.P are supported by PUPT Competitive Research Grant 2016 for UGM, Indonesia, Contract No. 661/UN1-P.III/LT/ DIT-LIT/2016. We thank Dr. Jose GutierrezMarcos, University of Warwick, England, for the gift of Agrobacterium tumefaciens strain EHA105 which contained T-DNA 35S::GAL4::AtRKD4::GR construct in plasmid pTA7002 that used in this research.
I.J. Biotech.

\section{References}

Aoyama, Tand Chua, N.1997. A glucocortioidmediated transcriptional induction system in transgenic plants. The Plant Journal 11(3) : 605-612.

Boutilier, K., Offringa, R., Sharma, V.K., Kieft, H., Oullet, T., Zhang, L. Hattori, J., Liu, C., van Lammeren, A.A.M., Miki, B.L.A., Custers, J.B.M. and Campagne, M.M.L. 2002. Ectopic expression of BABY BOOM triggers a conversion from vegetative to embryogenic growth. The Plant Cell 14: 1737-1749

Braybrook, S.A. and Harada, J.J. 2008. LECs go crazy in embryo development. Trends in Plant Science 13(12): 624-630.

Bunnag, S and Pilahome, W. 2012. Agrobacterium-mediated transformation of Dendrobium chrysotoxum Lindl. Afr. J. Biotechnol. 11(10): 2472-2476

Chan, Y.L., Lin, K.H., Sanjaya, Liao, L.J., Chen, W.H. and Chan, M.T. 2005. Gene stacking in Phalaenopsis orchid enhances dual tolerance to pathogen attack. Transgenic Res. 14: 279-288

Chardin, C., Girin, T., Roudier, F., Meyer, C. and Krapp, A. 2014. The plant RWP-RK transcription factors: Key regulators of nitrogen responses and gametophyte development. Journal of Experimental Botany. Doi:10.1093/jxb/eru261.

Dwiyani, R., Purwantoro, A., Indrianto, A., and Semiarti, E. 2010. Improvement of genetic transformation efficiency in Vanda tricolor orchid using acetosyringone. Annales Bogoriense 14 (2): 27-32

Green, M.R. and Sambrook, J. 2012. Molecular Cloning, A Laboratory Manual. Cold Spring Harbor Laboratory Press, Cold Spring Harbor, New York

Islam M.O., Ichihashi S., and Matsui S. 1998. Control of growth and development of protocorm like body derived from callus by carbon sources in Phalaenopsis. Plant Biotechnol. 15 (4): 183-187. 
Kang, H., Fang, Y. and Singh, K.B. 1999. A glucocorticoid-inducible transcription system causes severe growth defects in Arabidopsis and induces defense-related genes. The Plant Journal 20(1) : 127-133.

Kosir P., Skof S., and Luthar Z. 2004. Direct shoot regeneration from node of Phalaenopsis Orchid. Acta agriculture Slovenia 83: 233-242.

Kuta, D.D. and Tripathi, L. 2005. Agrobacteriuminduced hypersensitive necrotic reaction in plant cells: a resistance response against Agrobacterium-mediated DNA transfer. Afr. J. Biotechnol. 4(8): 752-757.

Liu Y, Lehman M. 2008. A genomic response to the yeast transcription factor GAL4 in Drosophila. Fly (Austin) 2 (2): 92-8.

McKinley, M. 2005. Complete Guide To Orchids: Ortho Books. American Orchid Society. USA. p.137.

Mishiba, K., Chin, D.P., and Mii, M. 2005. Agrobacterium-mediated transformation of Phalaenopsis by targeting protocorm at an early stage after germination. Plant Cell Rep 24: 297-303

Opabode, J.T. 2006. Agrobacterium-mediated transformation of plant: emerging factors that influence efficiency. Biotechnol. Mol. Biol. Rev 1(1): 12-20

Park, C., Canlas, P.E. and Ronald, P.C. 2012. Establishment of glucocorticoid-mediated transcriptional induction of the rice XA21 pattern recognition receptor. Journal of Plant Biology 55: 43-49

Radoeva, T and Weijers, D. 2014. A roadmap to embryo identity in plants. Trends in Plant Science 19 (11): 709-716.

Raffeiner, B., Serek, M., Winkelmann, T., 2009. Agrobacterium tumefaciensmediated transformation of Oncidium and Odontoglossum orchid species with the ethylene receptor mutant gene etr1-1. Plant Cell Tiss Organ Cult 98: 125-134

Schena, M., Lloyd, A., and Davis R.W. 1991. A steroid-inducible gene expression system for plant cells. Proc. Natl. Acad. Sci. USA 88: 10421-10425.
Semiarti E., Indrianto A., Purwantoro A., Isminingsih S., Suseno, N., Ishikawa T., Yoshioka Y., Machida Y., and Machida C. 2007. Agrobacterium-mediated transformation of the wild orchid species Phlaenopsis amabilis. Plant Biotechnology 24: 265-272.

Semiarti, E., Indrianto A., Suyono, E.A., Nurwulan, R.L., Mercuriani, I.S., Restiani R., Machida Y., and Machida C. 2010. Agrobacterium-mediated genetic transformation of black orchid Coelogyne pandurata Lindley. Proceeding of the third international conference on Mathemathics and natural Sciences, April 30, 2011, ISBN 978-979-17090-3-3, p. 455-465.

Shrestha, B.R, Chin, D.P, Tokuhara, K., and Mii, M. 2007. Efficient production of transgenic plantls of Vanda through sonication-assisted Agrobacterium-mediated transformation of protocorm-like bodies. Plant Biotechnol-Nar. 24: 429-434.

Subramaniam, S., Rathinam,X., Poobathy, R., and Sinniah, U. 2009. Establishment of in Vitro Phalaenopsis Violacea Plant Cultures from Flower-stalk Cuttings. Advances in Natural and Applied Sciences 3 (3): 432-437.

Sreeramanan S., and Zuraida A.R. 2010. Early GFP gene assessments influencing Agrobacterium tumefaciens transformation system in Phalaenopsis violacea orchid. Emir.J.Food Agric. 22(2): 103-116

Tang, C. and Chen, W. 2007. Breeding and development of new varieties in Phalaenopsis. In: Chen, W. and Chen, H. (Eds.). Orchid Biotechnology. World Scientific Publishing. Singapore. pp: 1-22.

Waki, T. Hiki, T., Watanabe, R., Hashimoto, T. and Nakajima, K. 2011. The Arabidopsis RWP-RK protein RKD4 triggers gene expression and pattern formation in early embriogenesis. Current Biology 21: 1277-1281.

Wysocka J, Herr W. 2003. “The herpes simplex virus VP16-induced complex: the makings of a regulatory switch". Trends Biochem. Sci. 28 (6): 294-304. 
Zhang, L., Chin, D.P., Fukami, M., Ichikawa, H., Nakamura, I., and Mii, M. 2010. Agrobacterium-mediated genetic transformation of Cattleya with an Odontoglossum ringspot virus replicase gene sequence. Plant Biotechnol-Nar. 27: 421-426.

Zuo, J., Niu, Q. and Chua, N. 2002. An estrogen receptor-based transactivator XVE mediates highly inducible gene expression in transgenic plants. The Plant Journal 24(2): 265-273. 